\title{
О НЕКОТОРЫХ ПРОБЛЕМАХ ПРИМЕНЕНИЯ ПРИНЦИПА ПОЛНОГО ВОЗМЕЩЕНИЯ ВРЕДА В ГРАЖДАНСКОМ ПРАВЕ РОССИЙСКОЙ ФЕДЕРАЦИИ
}

\section{PROBLEMS OF APPLYING THE PRINCIPLE OF FULL COMPENSATION FOR DAMAGES IN THE CIVIL LAW OF THE RUSSIAN FEDERATION}

I. Grigorieva

Summary: The article deals with the problems of observing the principles of full compensation for the caused losses and full reparation of the damage encountered in law enforcement practice, notes the difficulties of interpreting the related legislative provisions, analyzes the conclusions of the Constitutional Court of the Russian Federation on the issues under consideration.

The author proposes an approach based on the differentiation of the notions of «harm» and «loss», which makes it possible to fully implement the principle of full compensation for harm in legislation and court practice.

Keywords: civil law, harm, damage, loss, victim.

\author{
Григорьева Ирина Михайловна \\ К.ю.н., судья Арбитражного суда г. Москвы, \\ login8@mail.ru
}

Аннотация: В статье рассматриваются проблемы соблюдения принципов полного возмещения причиненных убытков и полного возмещения вреда, с которыми приходится сталкиваться в правоприменительной практике, отмечаются сложности толкования связанных с ними законодательных положений, анализируются выводы Конституционного Суда Российской Федерации по рассматриваемым вопросам.

Автором предлагается подход, основанный на разграничении понятий «вред» и «убытки» и позволяющий в полной мере реализовать принцип в03мещения вреда в законодательстве и судебной практике.

Ключевые слова: гражданское право, вред, ущерб, убытки, потерпевший. ринципы полного возмещения причиненных убытков и полного возмещения вреда, закрепляемые статьями 15 и 1064 Гражданского кодекса Российской Федерации (далее - ГК РФ), основываются на общечеловеческих представлениях о справедливости, разумности, добросовестности, необходимости защиты пострадавшей стороны от неблагоприятных для нее последствий противоправного поведения отдельных субъектов гражданского права, восстановления имущественной сферы потерпевшего за счет нарушителя.

Но несмотря на общепризнанность данных подходов их законодательное закрепление и реализация в правоприменительной практике оказываются непростой задачей. Данный вывод подтверждается, в частности, наличием целого ряда Постановлений Конституционного Суда Российской Федерации, посвященных выявлению конституционно-правового смысла оснований ответственности за причинение вреда, закрепляемых статьей 1064 ГК РФ (Постановления Конституционного Суда Российской Федерации от 10.03.2017 № 6-П, от 08.12.2017 № 39-П. 05.03.2019 № 14-П, От 18.11.2019 № 36-П, От 02.07.2020 № 32-П).

Во многом это связано с недостаточной определенностью самого понятия вреда в российском граждан- ском праве. Понятие «вред» зачастую отождествляется с такими понятиями, как «ущерб» и «убытки», причем в толковых словарях русского языка данные термины приводятся как синонимы, рассматриваются как равнозначные.

В научных публикациях можно встретить самые разные варианты определения понятия вреда и его соотношения с понятиями убытков и ущерба, а также признание возможности различных видов вреда и вариантов его определения. Так, в советский период развития отечественного гражданского права наряду с имущественным вредом выделяли понятия неимущественного, материального, нематериального, морального и даже «организационного» вреда [1, С. 50-57]. Справедливо отмечается наличие существенных особенностей определения понятия вреда в различных отраслях права, в том числе выделение в уголовном праве понятия «физического вреда» наряду с моральным вредом и имущественным вредом [4, С. 7-12].

Законодательство в ряде случаев фактически приравнивает понятия «вред» и «убытки» друг к другу. Так, в соответствии со статьей 1082 ГК РФ предусматривается, что вред может быть возмещен одним из двух способов: путем возмещения вреда в натуре (исправление 
поврежденной вещи, предоставление имущества, аналогичного утраченному, и т.п.) либо путем возмещения причиненных убытков.

Основываясь на буквальном толковании данных положений возможно полагать, что законодатель исходил из необходимости определения размера вреда как равного по величине размеру причиненных убытков, и, соответственно, наоборот, возможности точного определения размера причиненных убытков на основе определения размера причиненного имущественного вреда.

Однако анализ судебной практики показывает, что такая однозначность в оценках является ошибочной. Особый интерес в связи с этим представляет недавно принятое Постановление Конституционного Суда Российской Федерации от 28.04.2020 № 21-П «По делу о проверке конституционности положений статей 15 и 1064 Гражданского кодекса Российской Федерации в связи с жалобой гражданина А.Н. Музыки» [5].

Решением суда с лица, обратившегося с жалобой, были взысканы расходы на оплату услуг представителя (адвоката) по уголовному делу частного обвинения. Однако само уголовное дело было прекращено вследствие декриминализации деяния, в связи с чем возник вопрос о возможности и условиях возмещения понесенных потерпевшей стороной судебных расходов.

Конституционный Суд Российской Федерации отметил, что в соответствии с постановлением Пленума Верховного Суда Российской Федерации от 19.12.2013 № 42 [6] при прекращении уголовного дела в отношении обвиняемого, в том числе по нереабилитирующим основаниям, процессуальные издержки должны возмещаться за счет средств федерального бюджета, в связи с чем отсутствует возможность взыскания с лица, являвшегося обвиняемым, расходов, понесенных частным обвинителем на оплату услуг представителя.

Вместе с тем Конституционный Суд Российской Федерации отметил наличие в судебной практике неопределенности при решении вопросов возмещения указанных расходов, понесенных потерпевшим, при декриминализации деяния. Так, в связи с отсутствием для рассматриваемого случая однозначного решения вопроса о возмещении расходов потерпевшего в уголовно-процессуальном законодательстве, суды полагали, что такое возмещение может быть обеспечено за счет использования потерпевшим гражданско-правовых механизмов возмещения ущерба.

В рамках гражданско-правового подхода, исходя из буквального толкования законодательных положений, суды приходили к формально обоснованным выводам о том, что обязанность по возмещению процессуальных издержек должна лежать на лице, совершившем проти- воправное деяние, декриминализация которого сама по себе не делает его правомерным, а только освобождает нарушителя от уголовной ответственности за его совершение. Следовательно, расходы, понесенные потерпевшим, подлежали взысканию с причинителя вреда на основании положений статей 15 и 1064 ГК РФ.

Конституционный Суд Российской Федерации также указал на то, что в тех случаях, когда законом не предусматривается возмещение судебных расходов, понесшее их лицо может добиваться возмещения причиненных ему убытков в рамках отдельного судебного процесса при наличии оснований, предусмотренных статьей 15 ГК РФ.

Кроме того, Конституционный Суд Российской Федерации отметил, что положения пункта 1 статьи 1064 ГК РФ, предусматривающие обязанность полного возмещения вреда, причиненного личности или имуществу гражданина, направлены не на ограничение, а на защиту конституционных прав граждан [3]. Статья 15 ГК РФ также направлена на защиту прав участников гражданского оборота и обеспечение их восстановления за счет возмещения причиненных убытков, то есть в конечном итоге на реализацию конструкционного права неприкосновенности собственности, в связи с чем положения данной статьи не могут расцениваться как нарушающие конституционные права заявителя.

Конституционный Суд Российской Федерации отметил, что в случае совершения преступления у потерпевшего возникает право на возмещение понесенных им расходов в качестве убытков, причем основанием для их возмещения за счет нарушителя при декриминализации деяния и прекращении уголовного преследования является уже не само по себе противоправное поведение, в связи с которым было возбуждено дело, а те убытки, которые вынужден был понести потерпевший, в том числе в связи с уголовным процессом.

Таким образом, был сделан вывод о правомерности обоих подходов, несмотря на различия в результатах их применения: при первом из них убытки должно возмещать государство, но правовой механизм для их возмещения в рассматриваемом случае отсутствует, а при втором убытки должны возмещаться за счет нарушителя, противоправным поведением которого обусловлено их появление.

Конституционный Суд Российской Федерации пришел к выводу о том, что существует возможность различного толкования смысла оспариваемых законодательных положений, причем ни одно из них само по себе не вступает в противоречие с Конституцией Российской Федерации. Вместе с тем наличие возможности неоднозначного понимания положений статей 15 и 1064 ГК РФ по мнению Конституционного Суда Российской Федера- 
ции свидетельствует об их неопределенности, которая в свою очередь порождает возможность их произвольного применения, не позволяет гражданам предвидеть в полной мере последствия своего поведения, следовательно, противоречит принципам правовой определенности, равенства и справедливости, в силу чего не соответствует Конституции Российской Федерации.

Конституционный Суд Российской Федерации также отметил, что взыскание с обвиняемого возмещения убытков по правилам, предусмотренным статьями 15 и 1064 ГК РФ, в рассматриваемом случае может быть осуществлено со снижением размера выплат до разумных пределов с учетом декриминализации деяния и других обстоятельств дела, в том числе за счет установления рыночных значений стоимости юридических услуг на момент их оказания [2]. КС РФ отметил, в частности, что заявитель не являлся участником договора оказания правовых услуг и не мог повлиять на размер вознаграждения представителя другой стороны, в связи с чем он оказался поставлен в худшее положение по сравнению с осужденными лицами, с которых расходы взыскиваются в разумных пределах, определяемых под контролем суда.

В результате Конституционный Суд Российской Федерации постановил, что положения статей 15 и 1064 ГК РФ не соответствуют Конституции Российской Федерации в той мере, в какой они не обеспечивают надлежащего уровня правовой определенности.

Рассмотренный случай представляет особый интерес в связи с тем, что на данном примере видны основные недостатки доминирующего в настоящее время и получившего закрепление в законодательстве подхода, при котором вред и убытки рассматриваются как однозначным образом связанные понятия. В результате положения о возмещении вреда (статья 1082 ГК РФ) содержат отсылки к положениям о возмещении убытков (статья 15 ГК РФ), несмотря на принципиальные различия в тех целях, которым должны служить указанные категории.

Так, под вредом должны пониматься только непосредственно наступающие негативные последствия для личности или имущества гражданина либо имущества юридического лица. В этом отношении понятие вреда ближе к понятию ущерба, если к последнему относить только «утрату или повреждение имущества» (пункт 2 статьи 15 ГК РФ), чем к более широкому по своему содержанию понятию убытков, которое включает также упущенную выгоду и затраты, произведенные для восстановления нарушенного права. Следует отметить, что в судебной практике расходы, которые лицо вынуждено производить для восстановления своего права, также включаются в понятие «реальный ущерб», как это разъясняется, в частности, в пункте 13 Постановления Плену- ма Верховного Суда Российской Федерации № 6, Пленума Высшего Арбитражного Суда Российской Федерации № 8 от 01.07.1996 (в ред. от 25.12.2018) [7].

При оценке причиненного имущественного вреда, как представляется, необходимо руководствоваться именно оценкой умаления имущественной сферы потерпевшей стороны, в частности, стоимостью испорченной или утраченной вещи, расходами, необходимыми для приобретения сопоставимого аналога.

Все остальные расходы, связанные с причинением вреда, могут рассматриваться как составная часть убытков и должны оцениваться по правилам, установленным для возмещения убытков. При таком подходе расходы на ремонт, на транспортировку поврежденного имущества до места ремонта, его хранение или расходы на представителя, как в вышеописанном случае, должны рассматриваться как убытки, связанные с причинением вреда, но подлежащие взысканию сверх размера причиненного вреда.

Такие расходы для целей их возмещения могут оцениваться на основе определения рыночной стоимости соответствующих товаров, работ или услуг, что позволит судам принимать решения об их взыскании в полном объеме или частично с учетом обстоятельств каждого конкретного дела.

При этом у суда появится больше возможностей для гибкого определения размера взыскания с учетом особенностей каждого конкретного дела, а также установления условий, при которых соответствующие расходы могут рассматриваться в качестве связанных с причинением вреда, отграничения их от расходов, которые не могут быть однозначным образом отнесены к последствиям причинения вреда и, в частности, не связаны непосредственным образом с противоправным деянием, в результате совершения которого был причинен вред.

Предлагаемый подход позволит соблюдать важнейший для гражданского права принцип полного возмещения причиненного вреда, поскольку размер такого вреда будет определяться на основе показателей, допускающих объективную оценку. Полное возмещение вреда, как следует из приведенного выше вывода Конституционного Суда Российской Федерации, необходимо для обеспечения конституционного права неприкосновенности собственности.

Реализация предложенных подходов потребует, как представляется, внесения в законодательство существенных изменений, направленных на детализацию положений ГК РФ, посвященных регулированию вопросов, относящихся к возмещению вреда и убытков, причиняемых субъектам гражданского права. 


\section{ЛИТЕРАТУРА}

1. Красавчиков 0.А. Гражданские организационно-правовые отношения // Советское государство и право. 1966. С. 50-57.

2. Определение Конституционного Суда Российской Федерации от 02.04.2015 № 708-0 «По запросу Сюмсинского районного суда Удмуртской Республики 0 проверке конституционности положений пунктов 4 и 5 части первой статьи 135 Уголовно-процессуального кодекса Российской Федерации» // Вестник Конституционного Суда Российской Федерации. 2015. № 4.

3. Определение Конституционного Суда Российской Федерации от 10.02.2009 № 370-0-0 «06 отказе в принятии к рассмотрению жалобы граждан Мельниковой Людмилы Николаевны и Пономарева Александра Евгеньевича на нарушение их конституционных прав положениями пункта 1 статьи 1064 и статьи 1084 Гражданского кодекса Российской Федерации» // Справочно-правовая система «Консультант Плюс».

4. Пешкова 0.А. Соотношение понятий «вред», «убытки», «ущерб» // Мировой судья. 2010. № 7. С. 7-12.

5. Постановление Конституционного Суда Российской Федерации от 28.04.2020 № 21-П «По делу о проверке конституционности положений статей 15 и 1064 Гражданского кодекса Российской Федерации в связи с жалобой гражданина А.Н. Музыки» // Собрание законодательства Российской Федерации. 2020. № 20. Ст. 3225.

6. Постановление Пленума Верховного Суда Российской Федерации от 19.12.2013 № 42 (ред. от 15.05.2018) «0 практике применения судами законодательства о процессуальных издержках по уголовным делам» // Бюллетень Верховного Суда Российской Федерации. 2014. № 2.

7. Постановление Пленума Верховного Суда Российской Федерации № 6, Пленума Высшего Арбитражного Суда Российской Федерации № 8 от 01.07 .1996 (ред. от 25.12.2018) «0 некоторых вопросах, связанных с применением части первой Гражданского кодекса Российской Федерации» // Бюллетень Верховного Суда Российской Федерации. 2015. № 8.

(c) Григорьева Ирина Михайловна (login8@mail.ru).

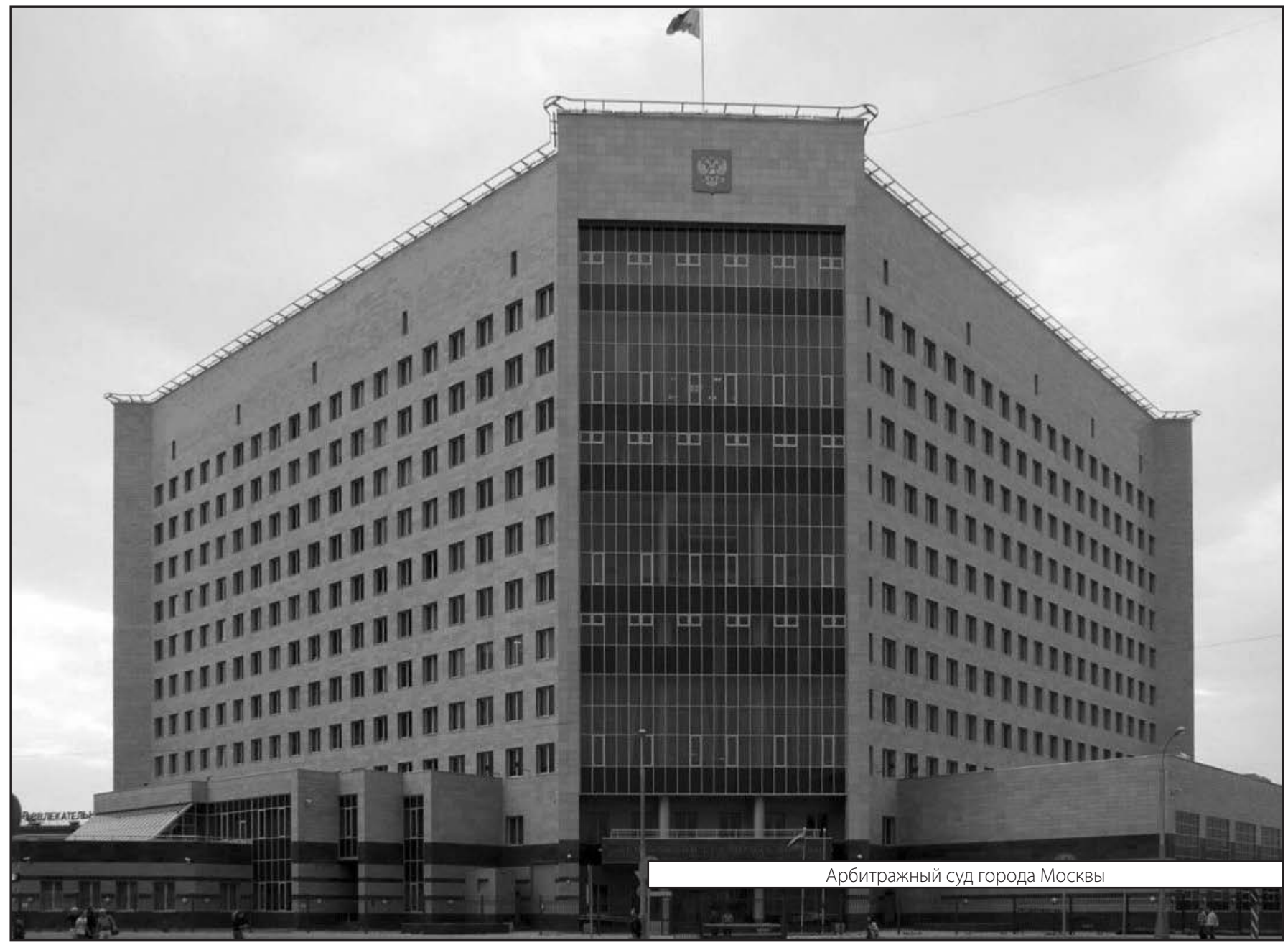

